\title{
IAMJ
}

INTERNATIONAL

AYURVEDIC

MEDICAL JOURNAL

\section{CLINICAL STUDY TO EVALUATE EFFICACY OF VIDANGADI LOHA AND HAMSA MANDOOR IN PANDU RIGS W.S.R TO IRON DEFICIENCY ANAEMIA}

\section{$\underline{\text { Sukhdev khatotra }}^{1}, \underline{\text { Samiksha Sharma }}^{2}$}

${ }^{1}$ Asstt Professor, ${ }^{2} \mathrm{PG}$ Scholar

Department of kayachiktsa, Jammu Institute of Ayurveda and Research, Jammu, India

Corresponding Author: samikshasharma2306@gmail.com

https://doi.org/10.46607/iamj0409062021

(Published Online: June 2021)

Open Access

(C) International Ayurvedic Medical Journal, India 2021

Article Received: 02/06/2021 - Peer Reviewed: 10/06/2021 - Accepted for Publication: 14/06/2021

Check for updates

\begin{abstract}
Nutritional indicators have been developed to monitor health for all. Greater emphasis is now placed on integrating nutrition into primary health care systems whenever possible and formulation of national dietary goals to promote health and nutritional status of families and communities. Iron deficiency has been recognized as commonest nutritional deficiency disorder and a risk to the nation among top ten selected health risks, although this deficiency disorder has been described by the name Panduroga thousands of years ago in the Ayurvedic classics. These Ayurvedic classics have also recommended formulations of Louha (iron) for the management of this disease as best remedy.
\end{abstract}

Keywords: Anemia, hemoglobin, iron deficiency, Pandu roga, serum ferritin

\section{INTRODUCTION}

Malnutrition either due to inadequate dietary intake or lack of balanced diet and population explosion in today's world has led to the development of various diseases and Pandu roga is one such disease.
A prominent diagnostic feature of Pandu roga is the pallor on the skin which occurs due to the quantitative and qualitative deficiency of rakta dhatu (blood tissue) caused either in the form of deficiency of hemoglobin 
and / or red blood cells (RBCs). Considering Panduta (pallor) as the predominant sign, the disease is termed as Pandu roga. The nearest correlation of iron deficiency anemia (IDA) can be made with Pandu roga, because of the predominance of Panduta or pallor in the whole body .Iron deficiency is a very common nutritional disorder worldwide and is known to affect approximately one third of the global population. While its incidence in affluent countries is low. With the aim that herbo-mineral medicines may be effective to manage IDA without any side effects, the present study was carried out to study the efficacy of an Ayurvedic herbo-mineral compounds Vidangadi louha \& Hamsa Mandoora With The Application Of Modern Parameters.

\section{MATERIALS AND METHODS:}

Study Design: A randomized, double-blind placebocontrolled clinical study was conducted in Patients suffering from IDA.

\section{Selection Of Cases:}

For the study the patients having the clinical features of Pandu roga (IDA) were selected.

\section{Inclusion Criteria:}

30 cases were selected on randomized basis to avoid bias from Jammu Institute of Ayurveda and Research, OPD

$>$ Age group of patients was maintained in between 12 years to 60 years.

$>$ A special detail clinical proforma has beA detail history was taken and complete physical examination was carried out.
Laboratory investigations like blood for complete haemogram, serum iron and

TIBC (total iron binding capacity) were carried out and a level of the parameters was fixed for diagnosis of patients as follows.

Haemoglobin percentage: Below $11.5 \mathrm{~g} / \mathrm{dl}$

Mean corpuscular volume (MCV): Below $76 \mathrm{fL}$

Serum iron (SI): Below $35 \mu \mathrm{g} / \mathrm{dl}$

Total iron binding capacity (TIBC)

More than $400 \mu \mathrm{g} / \mathrm{dl}$ Present

Saturation of transferrin: Less than 10.

\section{Exclusion Criteria:}

$>$ Haemoglobin percentage: Below $5 \mathrm{~g} / \mathrm{dl}$

$>$ Pregnant and lactating women

$>$ Iron deficiency anemia (Panduroga) with cardiac complication, diabetes mellitus and malignancy.

$>$ Iron deficiency anemia in a case of defective absorption. like patients of gastrectomy, gastrojejunostomy, sprue syndrome.

\section{Discontinuation Criteria:}

$>$ Blood hemoglobin level becomes less than $5 \mathrm{~g} / \mathrm{dL}$ during the course of treatment

$>$ Any other acute illness

$>$ Parents not willing to continue

$>$ Any severe untoward effect

Procurement of the drug: Both the trial drugs and the standard control were prepared in the pharmacy of Jammu Institute of Ayurveda and Research. Both the trial drugs and standard control were of similar physical character and were packed in similar types of packing.

Vidangadi Louha Hamsa mandooram

\begin{tabular}{|c|c|c|c|c|c|}
\hline S.No & $\begin{array}{l}\text { Name Of } \\
\text { The Ingredient }\end{array}$ & Proportion & S.No & $\begin{array}{l}\text { Name Of } \\
\text { The Ingredient }\end{array}$ & Proportion \\
\hline 1 & $\begin{array}{l}\text { Louha } \\
\text { Churnam }\end{array}$ & 1 Part & 1 & $\begin{array}{l}\text { Mandoora } \\
\text { Churnam }\end{array}$ & 1 Part \\
\hline 2 & Gomutram & 8 Parts & 2 & Gomutram & 8 Parts \\
\hline 3 & Vidanga & 1 Part & 3 & Vidanga & 1 Part \\
\hline 4 & Haritaki & 1 Part & 4 & Haritaki & 1 Part \\
\hline 5 & Amalaki & 1 Part & 5 & Amalaki & 1 Part \\
\hline 6 & Vibhitaki & 1 Part & 6 & Vibhitaki & 1 Part \\
\hline 7 & Musta & 1 Part & 7 & Musta & 1 Part \\
\hline 8 & Devadaru & 1 Part & 8 & Devadaru & 1 Part \\
\hline 9 & Sonti & 1 Part & 9 & Sonti & 1 Part \\
\hline
\end{tabular}




\begin{tabular}{|c|c|c|c|c|c|}
\hline 10 & Pippali & 1 Part & 10 & Pippali & 1 Part \\
\hline 11 & Maricha & 1 Part & 11 & Maricha & 1 Part \\
\hline 12 & $\begin{array}{l}\text { Pippali } \\
\text { Moola }\end{array}$ & 1 Part & 12 & $\begin{array}{l}\text { Pippali } \\
\text { Moola }\end{array}$ & 1 Part \\
\hline 13 & Chavya & 1 Part & 13 & Chavya & 1 Part \\
\hline 14 & Chitraka & 1 Part & 14 & Chitraka & 1 Part \\
\hline
\end{tabular}

\section{STUDY PROTOCOL:}

Total 30 patients were registered for the clinical trial and divided randomly into 3 groups, each containing 10 patients. Group-I and II were treated by VIDANGADI LOUHA and HAMSA MANDURA respectively. Group-III was treated by standard drug i.e. dried ferrous sulphate. The treatment schedule was continued for 30 days with twice daily doses of test Drugs and standard drug, patients were also followed up for next 30 days. Unwanted effects of drugs, if any during the total period (60 days) were noted, laboratory investigation of blood and serum of each patient was carried out before commencement and after completion of treatment.

Haematological parameters studied:

Blood was collected for performing haematological tests like Haemoglobin percentage, total RBC count,
Mean Corpuscular Volume, Mean Corpuscular Haemoglobin.

Biochemical parameters studied:

Serum was separated from blood and conducted tests for serum iron and total iron binding capacity.

Biochemical parameters were estimated in photometer5010 apparatus in biochemistry laboratory.

Grouping of patients:

Group Drug Dose (mg/day)

I VIDANGADI LOUHA 125

II HAMSA MANDURA 125

III (Standard control)

Dried ferrous sulphate 125

OBSERVATIONS AND RESULTS:

Effect of therapy on haematological parameters:

Table - 6.1: Effect of tests and standard drug preparations on haemoglobin percentage inpatients of 'Pandu roga' (iron deficiency anaemia)

\begin{tabular}{|c|c|c|c|c|c|c|}
\hline \multirow{3}{*}{ Group } & \multirow{3}{*}{$\begin{array}{c}\text { Dose } \\
(\mathrm{mg} / \text { day })\end{array}$} & \multicolumn{4}{|c|}{ Haemoglobin Content (g/dL) } & \multirow{3}{*}{ 'P' } \\
\hline & & $\begin{array}{c}\text { Before } \\
\text { Treatment }\end{array}$ & $\begin{array}{c}\text { After } \\
\text { Treatment }\end{array}$ & \multicolumn{2}{|l|}{ Change } & \\
\hline & & $\begin{array}{l}\text { Mean } \pm \\
\text { SEM }\end{array}$ & $\begin{array}{l}\text { Mean } \pm \\
\text { SEM }\end{array}$ & $\begin{array}{l}\text { Mean } \pm \\
\text { SEM }\end{array}$ & In $(\%)$ & \\
\hline Ferrous sulphate & 125 & $10.4 \pm 0.7$ & $11.2 \pm 0.9 \uparrow$ & $0.9 \pm 0.2 \uparrow$ & $08.6 \uparrow$ & $<0.01 * *$ \\
\hline $\begin{array}{l}\text { VIDANGADI } \\
\text { LOUHA }\end{array}$ & 125 & $09.4 \pm 0.7$ & $10.5 \pm 0.7 \uparrow$ & $1.1 \pm 0.2 \uparrow$ & $11.3 \uparrow$ & $<0.01 * *$ \\
\hline $\begin{array}{c}H A M S A \\
M A N D U R A\end{array}$ & 125 & $10.3 \pm 0.5$ & $12.0 \pm 0.5 \uparrow$ & $1.7 \pm 0.2 \uparrow$ & $16.9 \uparrow$ & $<0.001 * *$ \\
\hline
\end{tabular}

$\uparrow=$ Increase, $* *=$ Highly significant

The data pertaining to the effect of tests and standard drugs on haemoglobin percentage have been summarized in Table-6.1. A highly significant increase in haemoglobin percentage was observed in both the test drug groups and standard control group. It would be pertinent to note here that the percentage of increase in HAMSA MANDURA treated group is almost double in comparison to reference standard group. 
Table - 6.2: Effect of tests and standard drug preparations on total RBC count in patients of 'Pandu roga' (iron deficiency anaemia)

\begin{tabular}{|c|c|c|c|c|c|c|}
\hline \multirow{3}{*}{ Group } & \multirow{3}{*}{ Dose (mg/day) } & \multicolumn{4}{|c|}{ Total RBC Count $\left(10^{6} / \mu \mathrm{L}\right)$} & \multirow{3}{*}{ 'P' } \\
\hline & & Before Treatment & $\begin{array}{c}\text { After } \\
\text { Treatment }\end{array}$ & \multicolumn{2}{|l|}{ Change } & \\
\hline & & $\begin{array}{l}\text { Mean } \pm \\
\text { SEM }\end{array}$ & $\begin{array}{l}\text { Mean } \pm \\
\text { SEM }\end{array}$ & $\begin{array}{l}\text { Mean } \pm \\
\text { SEM }\end{array}$ & In $(\%)$ & \\
\hline Ferrous sulphate & 125 & $4.71 \pm 0.2$ & $4.68 \pm 0.2 \downarrow$ & $0.03 \pm 0.1 \downarrow$ & 0.64 & $>0.5$ \\
\hline $\begin{array}{l}\text { VIDANGADI } \\
\text { LOUHA }\end{array}$ & 125 & $4.27 \pm 0.3$ & $4.28 \pm 0.2 \uparrow$ & $0.01 \pm 0.1 \uparrow$ & 0.09 & $>0.5$ \\
\hline $\begin{array}{l}\text { HAMSA } \\
\text { MANDURA }\end{array}$ & 125 & $4.52 \pm 0.2$ & $4.64 \pm 0.2 \uparrow$ & $0.12 \pm 0.7 \uparrow$ & 2.43 & $>0.1$ \\
\hline
\end{tabular}

$\uparrow=$ Increase, $\downarrow=$ Decrease

A minute alteration in total RBC count was observed in all the groups, in standard control group, it was found to be decreased and was found to be increased in both test drug treated groups.

Table - 6.3: Effect of tests and standard drug preparations on Mean Corpuscular Volume in patients of 'Pandu roga' (iron deficiency anaemia)

\begin{tabular}{|c|c|c|c|c|c|c|c|c|c|}
\hline \multirow{4}{*}{$\begin{array}{l}\text { Group } \\
\text { Ferrous sulphate }\end{array}$} & \multirow{4}{*}{$\begin{array}{c}\begin{array}{c}\text { Dose } \\
\text { (mg/day) }\end{array} \\
125\end{array}$} & \multicolumn{7}{|c|}{ Mean Corpuscular Volume (MCV) (fL) } & \multirow{3}{*}{ 'P' } \\
\hline & & \multirow{2}{*}{\multicolumn{2}{|c|}{$\begin{array}{l}\text { Before } \\
\text { Mean } \pm\end{array}$}} & \multirow{2}{*}{\multicolumn{2}{|c|}{$\begin{array}{r}\text { After } \\
\text { Mean } \pm\end{array}$}} & \multicolumn{3}{|c|}{ Change } & \\
\hline & & & & & & Mea & & In $(\%)$ & \\
\hline & & $\begin{array}{l}70.7 \\
3.6\end{array}$ & \pm & $\begin{array}{l}75.5 \\
3.5 \uparrow\end{array}$ & \pm & $\begin{array}{l}4.8 \\
0.6 \uparrow\end{array}$ & \pm & $6.8 \uparrow$ & $\begin{array}{l}<0.001 * \\
*\end{array}$ \\
\hline $\begin{array}{l}\text { VIDANGADI } \\
\text { LOHADI }\end{array}$ & 125 & $\begin{array}{l}70.2 \\
3.3\end{array}$ & \pm & $\begin{array}{l}76.4 \\
1.5 \uparrow\end{array}$ & \pm & $\begin{array}{l}6.2 \\
2.0 \uparrow\end{array}$ & \pm & $8.8 \uparrow$ & $<0.02 *$ \\
\hline $\begin{array}{l}\text { HAMSA } \\
\text { MANDURA }\end{array}$ & 125 & $\begin{array}{l}71.0 \\
1.0\end{array}$ & \pm & $\begin{array}{l}76.2 \\
1.0 \uparrow\end{array}$ & \pm & $\begin{array}{l}5.2 \\
1.0 \uparrow\end{array}$ & \pm & $7.3 \uparrow$ & $\begin{array}{l}<0.001 * \\
*\end{array}$ \\
\hline
\end{tabular}

$* \uparrow$ - Increase, $*=$ Significant, $* *=$ Highly significant A statistically highly significant increase in Mean Corpuscular Volume was observed in both standard control and HAMSA MANDURA treated groups, whereas a statistically significant increase was found in VIDANGADI LOHA treated group. 
Table - 6.4: Effect of tests and standard drug preparations on Mean Corpuscular Haemoglobin in patients of 'Pandu roga' (iron deficiency anaemia)

\begin{tabular}{|c|c|c|c|c|c|c|c|c|c|}
\hline \multirow{3}{*}{ Group } & \multirow{3}{*}{$\begin{array}{c}\text { Dose } \\
\text { (mg/day) }\end{array}$} & \multicolumn{7}{|c|}{ Mean Corpuscular Haemoglobin (pg) } & \multirow{3}{*}{ 'P' } \\
\hline & & \multicolumn{2}{|c|}{$\begin{array}{l}\text { Before } \\
\text { Treatment }\end{array}$} & \multicolumn{2}{|c|}{$\begin{array}{l}\text { After } \\
\text { Treatment }\end{array}$} & \multicolumn{3}{|c|}{ Change } & \\
\hline & & $\begin{array}{l}\text { Mean } \\
\text { SEM }\end{array}$ & & $\begin{array}{l}\text { Mean } \\
\text { SEM }\end{array}$ & & $\begin{array}{l}\text { Mean } \\
\text { SEM }\end{array}$ & & In $(\%)$ & \\
\hline $\begin{array}{l}\text { Ferrous } \\
\text { sulphate }\end{array}$ & 125 & $\begin{array}{l}22.1 \\
1.6\end{array}$ & \pm & $\begin{array}{l}23.9 \\
1.6 \uparrow\end{array}$ & \pm & $\begin{array}{l}1.8 \\
0.5 \uparrow\end{array}$ & \pm & $08.1 \uparrow$ & $<0.01 * *$ \\
\hline $\begin{array}{l}\text { VIDANGAD } \\
\text { I LOUHA }\end{array}$ & 125 & $\begin{array}{l}22.3 \\
1.3\end{array}$ & \pm & $\begin{array}{l}24.4 \\
0.7 \uparrow\end{array}$ & \pm & $\begin{array}{l}2.1 \\
0.8 \uparrow\end{array}$ & \pm & $09.4 \uparrow$ & $<0.05^{*}$ \\
\hline $\begin{array}{l}\text { HAMSA } \\
\text { MANDURA }\end{array}$ & 125 & $\begin{array}{l}22.7 \\
0.5\end{array}$ & \pm & $\begin{array}{l}25.9 \\
0.5 \uparrow\end{array}$ & \pm & $\begin{array}{l}3.2 \\
0.4 \uparrow\end{array}$ & \pm & $14.1 \uparrow$ & $\begin{array}{l}<0.001 * \\
*\end{array}$ \\
\hline
\end{tabular}

$\uparrow=$ Increase, $*=$ Significant, $* *=$ Highly significant

A statistically highly significant increase in Mean Corpuscular Haemoglobin was observed in both standard control and HAMSA MANDURA treated groups, whereas statistically significant increase was found in VIDANGADI LOHA treated group

Table - 6.5: Preparations on serum iron level in patients of 'Pandu roga' (iron deficiency anaemia)

\begin{tabular}{|c|c|c|c|c|c|c|}
\hline \multirow{3}{*}{ Group } & \multirow{3}{*}{$\begin{array}{c}\text { Dose } \\
\text { (mg/day) }\end{array}$} & \multicolumn{4}{|c|}{ Serum Iron $(\mu \mathrm{g} / \mathrm{dL})$} & \multirow{3}{*}{ 'P' } \\
\hline & & \multirow{2}{*}{\begin{tabular}{l}
\multicolumn{1}{c}{ Before } \\
Treatment \\
Mean \pm \\
SEM
\end{tabular}} & \multirow{2}{*}{\begin{tabular}{l}
\multicolumn{1}{c}{ After } \\
Treatment \\
Mean \pm \\
SEM
\end{tabular}} & \multicolumn{2}{|l|}{ Change } & \\
\hline & & & & $\begin{array}{l}\text { Mean } \pm \\
\text { SEM }\end{array}$ & In $(\%)$ & \\
\hline $\begin{array}{l}\text { Ferrous } \\
\text { sulphate }\end{array}$ & 125 & $\begin{array}{l}31.3 \\
1.5\end{array}$ & $\begin{array}{l}39.0 \\
1.3 \uparrow\end{array}$ & $\begin{array}{l}07.6 \\
0.8 \uparrow\end{array}$ & $24.4 \uparrow$ & $\begin{array}{l}<0.001 * \\
*\end{array}$ \\
\hline $\begin{array}{l}\text { VIDANGAD I } \\
\text { LOUHA }\end{array}$ & 125 & $\begin{array}{l}29.1 \\
3.1 \\
\end{array}$ & $\begin{array}{l}38.8 \\
2.8 \uparrow\end{array}$ & $\begin{array}{l}09.2 \\
2.1 \uparrow\end{array}$ & $31.6 \uparrow$ & $<0.01 * *$ \\
\hline $\begin{array}{l}\text { HAMSA } \\
\text { MANDURA }\end{array}$ & 125 & $\begin{array}{l}29.0 \\
1.5\end{array}$ & $\begin{array}{l}40.1 \\
1.5 \uparrow\end{array}$ & $\begin{array}{l}11.1 \pm \\
1.7 \uparrow\end{array}$ & $38.1 \uparrow$ & $\begin{array}{l}<0.001 * \\
*\end{array}$ \\
\hline
\end{tabular}

$\uparrow=$ Increase $* *=$ Highly Significant

A statistically highly significant increase in serum iron level was observed in all the groups.

Table - 6.6: Effect of tests and standard drug preparations on total iron binding capacity in patients of 'Pandu roga' (iron deficiency anaemia)

\begin{tabular}{|c|c|c|c|c|c|c|}
\hline \multirow{3}{*}{ Group } & \multirow{3}{*}{$\begin{array}{c}\text { Dose } \\
\text { (mg/day) }\end{array}$} & \multicolumn{4}{|c|}{ nding Capacity (TIBC) $(\mu \mathrm{g} / \mathrm{dL})$} & \multirow{3}{*}{ 'P' } \\
\hline & & $\begin{array}{c}\text { Before } \\
\text { Treatment }\end{array}$ & $\begin{array}{c}\text { After } \\
\text { Treatment }\end{array}$ & \multicolumn{2}{|l|}{ Change } & \\
\hline & & Mean \pm & Mean \pm & Mean \pm & In (\%) & \\
\hline
\end{tabular}




\begin{tabular}{|c|c|c|c|c|c|c|}
\hline & & SEM & SEM & SEM & & \\
\hline Ferrous & \multirow[t]{2}{*}{125} & $434.9 \pm$ & $402.9 \pm$ & $32.0 \pm$ & \multirow[t]{2}{*}{$07.4 \downarrow$} & \multirow{2}{*}{$\begin{array}{l}<0.001 * \\
*\end{array}$} \\
\hline sulphate & & 19.0 & $16.0 \downarrow$ & $4.8 \downarrow$ & & \\
\hline \multirow[t]{2}{*}{ Vidangadilo } & \multirow[t]{2}{*}{125} & $474.3 \pm$ & $436.1 \pm$ & $38.1 \pm$ & \multirow[t]{2}{*}{$08.0 \downarrow$} & \multirow[t]{2}{*}{$<0.01^{\text {** }}$} \\
\hline & & 21.9 & $17.1 \downarrow$ & $7.1 \downarrow$ & & \\
\hline \multirow[t]{2}{*}{ Hamsa } & \multirow[t]{2}{*}{125} & $446.0 \pm$ & $390.9 \pm$ & $55.1 \pm$ & \multirow[t]{2}{*}{$12.4 \downarrow$} & \multirow[t]{2}{*}{$<0.01^{* *}$} \\
\hline & & 12.0 & $13.6 \downarrow$ & $9.7 \downarrow$ & & \\
\hline
\end{tabular}

$\downarrow=$ Decrease, $* *=$ Highly significant.

The data of effect of tests and standard drugs on total iron binding capacity (TIBC) have been summarized in Table - 6.6 A statistically highly significant decrease in total iron binding capacity was found in all the groups.

Table - 6.7: Effect of tests and standard drug preparations on percent saturation of transferrin in patients of 'Pandu roga' (iron deficiency anaemia)

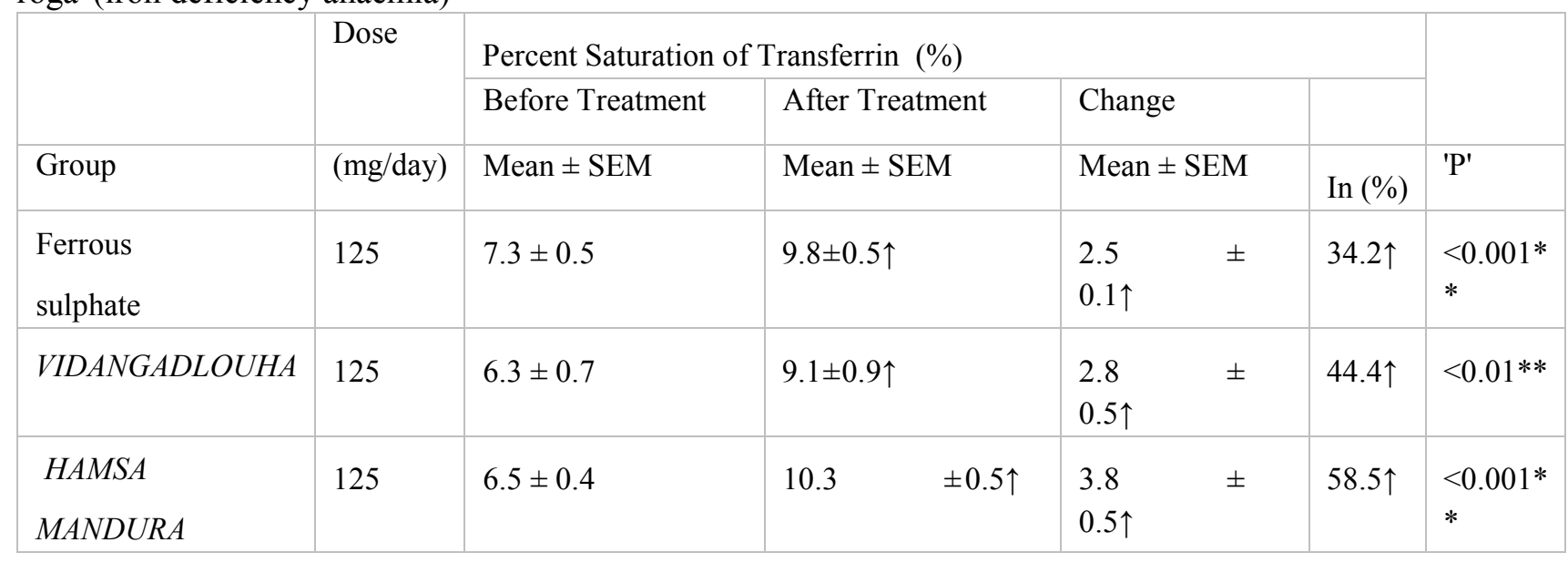

$\uparrow=$ Increase, $* *=$ Highly significant

The data revealing the effect of tests and standard drugs on percent saturation of transferrin have been presented in Table - 6.7. A highly significant increase in percent saturation of transferrin was observed in all the groups.

Overall effect of therapy on basis of laboratory investigations:

Table - 6.8: Effect of tests and standard drug preparations in patients of 'Pandu roga'(iron deficiency anaemia)

\begin{tabular}{|l|l|l|l|l|l|}
\hline Group & Dose (mg/day) & Improvement (\%) & Mild Improvement & No Change \\
\hline Ferrous sulphate & 125 & Marked Improvement & Moderate Improvement & Mid \\
\hline $\begin{array}{l}\text { VIDANGADI } \\
\text { LOHA }\end{array}$ & 125 & 00.0 & 50.0 & 50.0 & 00 \\
\hline $\begin{array}{l}\text { HAMSA } \\
\text { MANDURRA }\end{array}$ & 125 & 14.4 & 42.8 & 42.8 & 00 \\
\hline Overall effect & - & 28.7 & 57.1 & 14.4 & 00 \\
\hline
\end{tabular}


The data pertaining to the effect of tests and standard drugs on improvement in patients on the basis of laboratory investigation have been summarized in Table -6.8. Moderate Improvement in 50\% patients and mild improvement in another $50 \%$ of patients were observed in standard control group. Marked improvement in $14.4 \%$ of patients, moderate improvement in $42.8 \%$ of patients and mild improvement in $42.8 \%$ of patients were found in VIDANGADI LOUHA treated group. Marked improvement in $28.7 \%$ of patients, moderate improvement in $57.1 \%$ of patients and mild improvement in $14.4 \%$ of patients were noticed in HAMSA MANDURA treated group. Out of 30 patients registered, 52 patients have completed the treatment schedule, among them, marked improvement in $13.6 \%$ of patients, moderate improvement in $50 \%$ of patients and mild improvement in $36.4 \%$ of patients were observed on the basis of improvement in haemoglobin percentage, serum iron and total iron binding capacity.

\section{DISCUSSION}

Families of poor income group are unable to afford proper diet due to improper and imbalanced diet. As per the WHO report iron deficiency is the most common among groups of low socio-economic status. The disease Pandu roga is equally prevalent in both Vegetarians and non-vegetarians. The disease is more prevalent in the Prakriti dominant in Pitta. As Pandu roga is Pitta dominant tridoshaja vikara (disease caused due to anomalous behaviour of all the three doshas) and under-nutrition is commonly found in Vata dominant persons. So probably this might be the reason of majority of patients being of Vata-Pitta Prakriti group in the present study. Mandagni and Madhyama koshtha are observed in maximum patients. Consuming insufficient diet due to Mandagni leads to malnutrition, the root cause of disease. According to Ayurveda abnormal function of Agni is the root cause of all diseases. Madhyama Koshtha showing dominance of Kapha leads to improper digestion, which is the important cause of any disease. Kapha Dosha is predominant during childhood period and kapha dosha also plays an important role in the pathogenesis of the disease.

After 30 days treatment with the trial drug, highly significant improvement was observed in the clinical features of IDA with $\mathrm{P}$ value $<0.001$. After 20 s of medication comparatively faster improvements were observed in the clinical features such as pallor, anorexia, weakness, fatigue, irritability. Clinical features of Pandu roga (IDA) are mainly due to quantitative and qualitative reduction of $\mathrm{Hb}$ and less oxygen supply in the tissues. $1 \mathrm{~g} \%$ hemoglobin, when fully Saturated, combines with $1.34 \mathrm{ml}$ of oxygen, therefore, hemoglobin Concentration is an index of oxygen Carrying capacity of blood. With the trial drugs therapy hemoglobin status improves, body tissues get adequate oxygen, body metabolism improves, and ultimately relief in clinical symptoms is observed.

The present clinical study shows the hematinic potential of Vidangadi louha \& Hamsa mandoora, It is evident that the treatment of iron deficiency Anemia with Hamsa mandoora shows statistically significant increase of hematologic values, such as blood $\mathrm{Hb} \%$, total $\mathrm{RBC}, \mathrm{PCV}, \mathrm{MCV}, \mathrm{MCH}$, and so on. Blood hemoglobin level was improved significantly with a mean increase of $1.94 \mathrm{~g} / \mathrm{dL}$ in 20 days (8.52-10.46 g/dL, $\mathrm{P}<0.001)$ and $3.33 \mathrm{~g} / \mathrm{dL}$

in 30 days $(8.52-11.85 \mathrm{~g} / \mathrm{dL}, \mathrm{P}<0.001)$. After 30 days treatment in the trial groups, $\mathrm{Hb}$ was increased by $11.3 \%$ in Vidangadi louha group and $16.9 \%$ in Hamsa Mandoora group.

Hamsa Mandoora is more effective than Vidangadi louha. Vidangadi louha \& Hamsa mandora are Ayurvedic herbo-mineral drugs containing same combination except louha basma in Vidangadi louha \& Mandoora basma in Hamsa mandoora. The trial drugs contain herbal drugs like Triphala, which is rejuvenative; Trikatu, which is an appetizer; and Trimada, which is digestive. Herbal ingredients in the trial drug may increase the bioavailability of Mandura bhasma and louha bhasma which are important contents of the formulation. About $10 \%$ of iron in an average Indian diet is normally absorbed. More is absorbed during deficiency states.

Iron deficient state absorbs about $30 \%$ of dietary iron. Effectiveness of Haritaki, Mandura Bhasma, and 
Louha Bhasma to increase blood hemoglobin level has been proved scientifically by previous research studies. Amalaki (Emblica officinalis) is richest source of Vitamin Vitamin C reduces ferric iron to ferrous iron, which remains soluble even at neutral $\mathrm{pH}$ and is better absorbed.

Amalaki enhances the production of RBCs and increases immunity in the body. Pippali is a proved drug to increase bioavailability. Triphala have Anulomana property and counteract the constipative effect of iron compounds like Louha Bhasma and Mandura Bhasma.

Long-term treatment is needed for the treatment of IDA and Hamsa mandoora can be prescribed for long-term period without any adverse effect in patients.

\section{CONCLUSION}

Vidangadi louha \& Hamsa mandoora have been subjected to a clinical study on patients suffering from IDA. They contain iron (Mandura Bhasma and Louha Bhasma) and herbal ingredients (Triphala, Trikatu, and Trimada). Herbal ingredients present in the trial drug may increase the bioavailability of iron. Hematinic action of Hamsa mandoora may be due to the presence of iron contents of good bioavailability. The present clinical study clearly indicates that the herbo-mineral formulation Hamsa mandoora is an effective, welltolerated, and clinically safe formulation for the management of IDA than Vidangadi louha.

\section{REFERENCES}

1. Brahmanand Tripathi. Varanasi: Chaukhambha Surbharati Prakashan; 1997. Hindi Commentator, Charaka Samhita.

2. N.F.H.S 3rd. International Institute for Population Science; 2006. National Family Health Survey for India conducted by Mumbai, India.

3. Das AK. 1st ed. Calcutta: Books and Allied (P) Ltd; 2000. Medical Physiology; p. 726.

4. Satoskar RS, Bhandarkar SD, Ainapure SS. 16th ed. Mumbai: Popular Prakshan Pvt. Ltd; 1999.Pharmacology and Pharmacotherapeutics; p. 47

5. Geneva: World Health Organisation; 2001. [Last accessed on 2011 Nov 20]. Iron Deficiency Anaemia Assessment, Prevention, and Control; p. 21.
6. Gupta V, Reddy KR. Clinical Evaluation of Lohasava in the Management of Pandu Roga. Ayu. 2007; 28:49-56.

7. Thaman OP. New Delhi: Tata McGraw-Hill Publishing Company Limited; 1985. Textbook of Pediatrics; p. 259. (590).

8. Banerjee A. New York: Published in the United States of America by Cambridge University Press; 1st ed. New York: Published in the United States of America by CambridgeUniversity; 2005. Clinical Physiology; p. 151.

9. Ghosh S. New Delhi: Voluntary Health association of India; 1985. The Feeding and Care of Infants and Young Children; p. 24.

10. Bnnett B. 19th ed. New Delhi: Elsevier; 2005. Clinical Pharmacology; p. 587.

11. Kumath V. On Pandu Roga, MD thesis. P. G. Department. of Dravyaguna, Government. Ujjain, Madhya Pradesh: Autonomous Dhanvantari Ayurveda College and Hospital; 2006. A Comprehensive Study of Haritaki with Special Reference to the Efficacy of Terminalia Chebula Retz.

12. Agrawal N. P.G. Department of Kaumarbhritya. Varanasi: IMS, B.H.U; 2007. Assessment of Effect of Mandura Bhasma in Iron Deficiency Anemia in Children, MD thesis.

13. Sarkar PK, Prajapati PK, Choudhary AK, Shukla VJ, Ravishankar B. Haematinic Evaluation of LauhaBhasma and Mandura Bhasma on $\mathrm{HgCl} 2$-induced Anemia in Rats. Indian J Pharm Sci. 2007; 69:791-5.

14. Sarkar PK. I.P.G.T. \& R.A. Jamnagar: Gujrat Ayurveda University; 2005. A Comparative Pharmaceuticopharmaco-clinical study of Lauha Bhasma and Mandura Bhasma w.s.r. to its Pandu-hara Effect, MD thesis.

15. Garai A, Rai M, Kumar A. Role of an Ayurvedic Compound (Panduhara Yoga) in the Management of IronDeficiency Anaemia in Children. Ayu. 2009; 30:469-74.

16. Gupta V, Reddy KR. Experimental Studies of Lohasava. Aryavaidyan.18. Joshi N. P. G. Department of Rasa Shastra and Bhaishajya Kalpana, Jaipur: N.I.A; 2005. Pharmacological

and Toxicological Study of Various Lauha Preparations (Kalpa) w.s.r. to Iron Deficiency Anaemia, M.D. Thesis.

17. Sarkar PK, Prajapati PK, Shukla VJ, Ravishankar B, Choudhary AK. Toxicity and recovery studies of two Ayurvedic preparations of iron. Indian J Exp Biol. 2009; 47:987-92. [PubMed] 
18. Devarshi P, Kanse A, Kanse R, Mane S, Patil S, Varute AT. Effect of Mandura Bhasma on lipolytic Activities of Liver, Kidney and Adipose Tissue of Albino Rat During CC14 Induced hepatic Injury. J Biosci. 1986; 10:227-34.

19. Pandit S, Biswas TK, Debnath PK, Saha AV, Chowdhury U, Shaw BP, et al. Chemical and pharmacological evaluation of different Ayurvedic preparations of iron. J Ethnopharmacol. 1999; 65:149_ 56. [PubMed]

20. Rajeshwarduttashastri Bhaishajyaratnavali of Govinddas, Pandurogchikitsa prakaranam: Chapter 12, verse 38-43. Varanasi Chaukhamba Sanskrit Sansthan. (11th ed) 1993:270-271.

\section{Source of Support: Nil \\ Conflict of Interest: None Declared}

How to cite this URL: Sukhdev \& Samiksha Sharma: Clinical Study To Evaluate Efficacy Of Vidangadi Loha And Hamsa Mandoor In Pandu Rigs W.S.R To Iron Deficiency Anaemia. International Ayurvedic Medical Journal \{online\} 2021 \{cited June, 2021\} Available from: http://www.iamj.in/posts/images/upload/1181_1189.pdf 